\title{
EXPANSION OF AGRICULTURAL AREAS IN BRAZIL FROM 1994 TO 2013: SOYBEANS VERSUS CORN VERSUS COTTON
}

\author{
Expansão de Área Agrícola no Brasil de 1994 a 2013: Soja Versus Milho versus Algodão
}

\begin{abstract}
The objective of this article was to map disparities in the increases of agricultural areas in the Brazilian mesoregions between 1994 and 2013; particularly the levels of concentration of soybeans, corn, and cotton. The methodological approach included Cluster procedures and locational Gini coefficients. The results highlighted a frontier line identified in the central-northwest area of Brazil. As for the crops, a more concentrated expansion of the agricultural area dedicated to cotton was verified in the selected mesoregions. This expansion was less concentrated in soybeans and even less concentrated in corn.

Rogério Edivaldo Freitas

Instituto de Pesquisa Econômica Aplicada

rogerio@dep.ufscar.br

DOI: $10.21714 / 2238-68902017 v 19 n 3 p 219$

\section{RESUMO}

O objetivo deste artigo foi mapear as diferenças em expansão de área agrícola no âmbito das mesorregiões brasileiras no período 1994-2013, com foco nas parcelas devidas à soja, ao milho e ao algodão neste processo. Empregaram-se, como abordagem metodológica, procedimentos de análise de clusters e coeficientes locacionais. Uma fronteira de expansão agrícola foi identificada no sentido Centro-Noroeste do Brasil. Em relação às culturas avaliadas, a expansão de área agrícola nas mesorregiões selecionadas foi mais expressiva nas áreas algodão cultivadas. Essa expansão foi comparativamente menos soja concentrada e (ainda menos) milho concentrada.
\end{abstract}

Palavras Chave: Agricultura, Uso de Solo, Safras, Análise de Cluster, Brasil.

Keywords: Agriculture, Land Use, Crops, Cluster Analysis, Brazil.

\section{INTRODUCTION AND OBJECTIVE}

Between 1930 and 1980, Brazil transitioned from its status as a nearly monocultural producer to a country with diversified agricultural production (BRANDÃO, 2002; FREITAS, 2014a). In order to meet the country's needs with regard to food security and safety, investments and subsidies for research were directed toward Brazilian agriculture (BARROS, 2002; MARIN et all, 2016), and led to a significant production increase during the last forty years.

In the first half of the $90 \mathrm{~s}$, domestic producers had greater exposure to international markets, which created new difficulties for Brazilian farmers. This scenario continued until 1994, especially with regard to inflation, and the sector was severely damaged because of the time lag between sowing and harvest operations. These events led to learning and solidity in the sector, which today is a main sector in the Brazilian economy. However, strategic adjustments had a variety of scattered impacts on the regions and on different crops.

On the other hand, food production remains a central concern for humanity in the twenty-first century. According to the United Nations (2015), the world population will reach 9.5 billion in 2050 , and the urbanization is a notorious process in the larger developing countries in Africa, and in China and India. Meanwhile, the major food producing countries (Russia, the United States, Argentina, Canada, and Australia) do not have any more land for economically or technically profitable farming.

For Bruinsma (2009), much of the land that already employed has some sort of constraint that cannot be easily overcome (chemical, physical, endemic diseases, or lack of infrastructure). Some of this land is covered with forests, protected areas or host settlements, for example. Moreover, agricultural systems in Africa and Southeast Asia appear to be vulnerable in terms of land productivity changes and consistent changes in water demand against the backdrop of an evolving climate (IGLESIAS, QUIROGA and DIZ, 2011).

Within this scenario, Brazil emerges as an important player for future increases in agricultural area, agricultural productivity, and food production. According to Brosig et al. (2012), Brazil's resources allow an excess production for exports. Brazil is already an important player in several agricultural markets, such as soybeans, sugar, and meat (beef, pork and poultry), and it is expected to maintain or even expand its share by 2023 (OECD-FAO, 2014). 
In international poultry markets, for instance, Brazil has overtaken the United States as the world's largest exporter based on productivity gains, as indicated in Valdes, Hallahan and Harvey (2015). At the same time, Brazil's agricultural area is expanding into new spaces in Northeast states, increasing land prices (GASQUES, BOTELHO and BASTOS, 2014).

Therefore, the objective of this article is to map disparities in the increases of agricultural areas among the Brazilian mesoregions between 1994 and 2013; particularly the levels of concentration for soybeans, corn, and cotton. These three crops accounted for $50 \%$ of the production value of Brazilian temporary crops in the period 2010-2013 (IBGE, 2015). Soybeans and corn are also important components of animal feed for dairy and meat farming with impacts on domestic food prices and are main products among Brazilian agricultural exports (SANTO, LIMA and SOUZA, 2012; FREITAS, 2014b).

\section{METHODOLOGY AND DATA}

This study employed data from IBGE (2015) from 1994 to 2013 on production value, harvested area, and planted area, at the mesoregion level. The study applied two processes to measure the rates of increase in agricultural area; firstly, the percentages of mean increase in agricultural area were calculated for Brazilian mesoregions according to equations (1) and (2):

$I_{1 i}=\sum_{t}^{T}\left(C_{94, t}\right) / 19 \quad \mathrm{t}=1995, \ldots, 2013$

where $\mathrm{C}_{94, t}$ is the growth rate for planted area by ${ }_{i}$ Mesoregion in ${ }_{t}$ year compared with 1994.

As an additional control related to the effects of climatic conditions on agricultural production and also to capture short-term conditions, Indicator $1\left(\mathrm{I}_{1}\right)$ was measured exclusively for the period 2009-2013.

$I_{2 i}=\sum_{t}^{T}\left(C_{94, t}\right) / 5 \quad \mathrm{t}=2009, \ldots, 2013$.

Euclidean distance was also used; this is defined as a function of the $\mathrm{X}$ variables associated with two sample elements, and can be expressed as (3), where $p$ are variables or characteristics of each sample element and $\mathrm{k}$ is the number of elements.

$d\left(X_{1}, X_{k}\right)=\left[\left(X_{1}-X_{k}\right)\left(X_{1}-X_{k}\right)\right]^{1 / 2}=\left[\sum_{i=1}^{p}\left(X_{i 1}-X_{i k}\right)^{2}\right]^{1 / 2}$
An additional variable entitled Lost Area (LA) was also calculated; this corresponds to the difference between planted area (PA, intended crop) and harvested area (HA, effective harvest). As discussed by Zhao, Hitzhusen, and Chern (1991), soil erosion and land degradation have been destructive worldwide. Because of reasons such as high population pressure on land and limited fossil energy supplies, land degradation is generally more serious in the developing world. Generally, planted area is represented as a function of agricultural product market prices, input prices, and technological conditions in field operations. Meanwhile, harvested area is a function of the same variables that affect planted area as well as random variables such as climatic conditions and the incidence of pest attack and diseases, for example. As a result, LA is also a random variable.

In practical terms, four key variables were used to measure the growth of agricultural area among the Brazilian mesoregions: planted area (PA), harvested area $(\mathrm{HA})$, production value $(\mathrm{PV})$, and LA, where:

$$
L A=P A-H A \quad \mathrm{t}=1994, \ldots, \mathrm{T}
$$

Two steps compose the calculations. Initially, the agglomerative hierarchical method was employed to indicate the number of groups that better fit the data. In the second round, within a year-by-year analysis, pseudo-T and pseudo-F tests ${ }^{1}$ were run. These tests indicate the number of groups that produce the best gains of information. The calculations were done using the variables expressed in growth rates (planted area), in absolute values (planted area, lost area), or normalized values (planted area, lost area, and production value).

The next stage of the methodological approach employed the Locational Quotient (LQ) and the locational Gini coefficient (LGC). LGC has been employed by Krugman (1991) for analyzing location dynamics, and other studies have highlighted its benefits related to ease of implementation and data requirements (BERTINELLI and DECROP, 2005; VAN DEN HEUVEL, DE LANGEN and FRANSOO, 2013).

This tool had also been employed in studies extending beyond agricultural analyses, for instance, for studying regional specialization in China (LU, FLEGGB and DENGE, 2011), for identifying industrial reallocations (RUAN and ZHANG, 2014) and for identifying high-tech concentrations (DEVEREUX, GRIFFITH and SIMPSON, 2004). Reveiu and Dardala (2011) also applied LQ to investigate employment statistics in Romania's counties.

${ }^{1}$ These tests are standard for this methodology as described in Mingoti (2005) and SAS (2014a). 
LQ indicates whether the relative importance of a specific mesoregion is greater for one crop than for all (permanent and temporary) crops combined. From LQ, it is possible to calculate LGC, which is useful for analyzing the spatial concentration of a crop in a specific area, and for identifying whether a crop is specialized in certain regions.

Based on Haddad's discussion of LQ (1989) and Isard (1960), LQ is defined as the following equation for soybeans:

$L Q_{i j}=\left(S_{i j} / S_{i^{*}}\right) /\left(A_{* j} / A_{* *}\right)$

where:

$S_{i j}=$ planted area with soybeans in mesoregion $j$;

$S_{i^{*}}=$ planted area with soybeans in all mesoregions;

$A_{* j}=$ planted area in mesoregion $j$;

$A_{* *}=$ planted area in all mesoregions.

In this context, $\left(S_{i j} / S_{i^{*}}\right)$ is the relative importance of mesoregion $j$ in the planted area with soybeans and $\left(A_{* j} / A_{* *}\right)$ is the relative importance of mesoregion $j$ in the combined planted area for all crops. LQ was also calculated in the same way for corn and cotton.

For dealing with large areas (mesoregions), the first step was to organize them by decreasing LQ for a chosen variable (planted area with soybeans, for example). Next, a localization curve was constructed for the chosen crop, and the curve point generators result as follows:

- Y coordinates were derived from the accumulated share of the chosen variable (planted area with soybeans, for example) in the mesoregions;

- X coordinates were derived from the accumulated share of the same variable (planted area) for all crops (temporary and permanent) in the mesoregions.

In both cases, the order in which data enter obeys the descending order of the LQ. In a hypothetical case of five mesoregions, the final curve would contain five points, as shown in Figure 1.

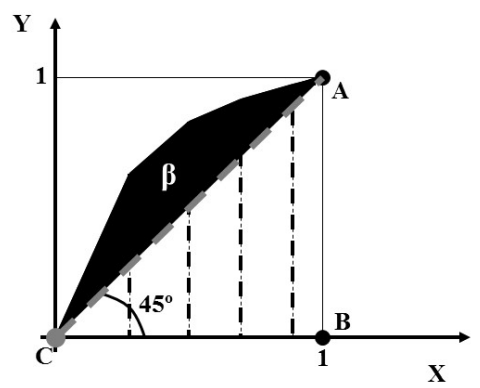

FIGURE 1 - LGC concentration area Source: based on Krugman (1991) and Suzigan et al. (2003)
LGC is the ratio between the area represented by $\beta$ (above) and the area of the $\mathrm{ABC}$ triangle, which is restricted by a $45^{\circ}$ line. Consequently:

$L G C=(\beta / 0.5)=2 . \beta$

Then, the maximum value for $\mathrm{LGC}=1$, because the maximum value for $\beta$ is 0.5 . According to Suzigan et al. (2003), the closer the value is to 1 , the more spatially concentrated the crop being analyzed is, and vice versa. In the context of a large country like Brazil, LGC will naturally tend to be relatively lower because of the dimensions of the individual mesoregions, which in many cases are larger than some European countries.

\section{RESULTS}

This section is composed of two subsections: the first describes the more representative mesoregions in terms of agricultural area growth rate, and the second describes the shares of soybeans, corn, and cotton in this process.

\subsection{Selected Mesoregions}

It is possible to distinguish two periods of growth in Brazil's agricultural areas between 1994 and 2013: 1994-2001 and 2002-2013.

Table 1 shows that between 1995 and 2001, planted areas were always smaller than the respective data for 1994 , the mean growth rate was negative $(-0.22 \%$ per year). Particularly during the period 1996-1998, there was a significant reduction compared to the 1994 base data. Afterwards, Brazilian agricultural areas recovered and expanded from 2002 to 2013, resulting in a mean growth rate of $2.91 \%$ per year during this period and a rising compound growth rate.

TABLE 1 - Brazil's planted areas and growth rates for agricultural areas, 1994-2013

\begin{tabular}{ccc}
\hline Year & Planted area (hectares) & Growth rates $_{(t / t-1)}$ \\
\hline 1994 & $52,815,030$ & - \\
1995 & $51,853,110$ & $-1.82 \%$ \\
1996 & $46,821,814$ & $-9.70 \%$ \\
1997 & $48,302,405$ & $3.16 \%$ \\
1998 & $48,509,074$ & $0.43 \%$ \\
1999 & $50,700,694$ & $4.52 \%$ \\
2000 & $51,819,125$ & $2.21 \%$ \\
2001 & $51,637,167$ & $-0.35 \%$ \\
\hline
\end{tabular}

Continua... 
TABLE 1 - Continuation...

\begin{tabular}{|c|c|c|}
\hline Year & Planted area (hectares) & Growth rates $_{(t / t-1)}$ \\
\hline 2002 & $54,511,629$ & $5.57 \%$ \\
\hline 2003 & $58,460,983$ & $7.24 \%$ \\
\hline 2004 & $63,036,966$ & $7.83 \%$ \\
\hline 2005 & $64,319,313$ & $2.03 \%$ \\
\hline 2006 & $62,563,908$ & $-2.73 \%$ \\
\hline 2007 & $62,338,730$ & $-0.36 \%$ \\
\hline 2008 & $65,527,804$ & $5.12 \%$ \\
\hline 2009 & $65,721,594$ & $0.30 \%$ \\
\hline 2010 & $65,374,591$ & $-0.53 \%$ \\
\hline 2011 & $68,158,023$ & $4.26 \%$ \\
\hline 2012 & $69,196,172$ & $1.52 \%$ \\
\hline 2013 & $72,434,134$ & $4.68 \%$ \\
\hline \multirow{2}{*}{\multicolumn{2}{|c|}{$\begin{array}{c}\text { Average 1995-2001 } \\
\text { Standard deviation 1995-2001 }\end{array}$}} & $-0.22 \%$ \\
\hline & & $4.70 \%$ \\
\hline \multicolumn{2}{|c|}{ Compound growth rate $1995-2001$} & $18 \%$ \\
\hline \multicolumn{2}{|r|}{ Average 2002-2013 } & $2.91 \%$ \\
\hline \multicolumn{2}{|c|}{ Standard deviation 2002-2013 } & $3.35 \%$ \\
\hline \multicolumn{2}{|c|}{ Compound growth rate $2002-2013$} & $46 \%$ \\
\hline
\end{tabular}

Source: author based on data on Municipal Agricultural Production (IBGE, 2015)

As highlighted by Awokuse and Xie (2015), the remarkable expansion of the agricultural sector in Brazil made notable contributions to the growth of the overall economy, especially in terms of Brazil becoming a top producer and exporter of beef, broiler chickens, coffee, soybeans and oilseeds, sugar, and ethanol derived from sugarcane. According to Doğan, Arslan, and Köksal (2013) the agricultural sector has changed in recent years, taking on such diverse roles as direct/indirect contributions to feeding the population, national income, employment, supplying raw materials to industry, exports, and biological diversity.

Table 2 shows the Brazilian mesoregions in which both indicators $I_{1}$ and $I_{2}$ exceeded the respective values in terms of national means; in other words, in terms of Brazilian growth rates for agricultural area compared with $1994^{2}$. Forty-two mesoregions met both criteria. Geographically, these regions were located in the following regions: 11 in the north, 10 in the center-west, 9 in the south, 8 in the southeast, and 4 in the northeast. Note that half were in the North or Center-West-regions.

${ }^{2}$ The national mean for $I_{1}$ was $11.74 \%$ and for $I_{2}$ was $29.09 \%$.
TABLE 2 - Selected mesoregions according to growth rates in planted area, 1994-2013

\begin{tabular}{|c|c|}
\hline North Amapá - AP & $\begin{array}{c}\text { Central-West Rio Grande do } \\
\text { Sul - RS }\end{array}$ \\
\hline East Tocantins - TO & $\begin{array}{c}\text { Central-North Mato Grosso } \\
\text { do Sul - MS }\end{array}$ \\
\hline South Amapá - AP & Southwest Mato Grosso - MT \\
\hline North Mato Grosso - MT & $\begin{array}{c}\text { Northeast Rio Grande } \\
\text { do Sul - RS }\end{array}$ \\
\hline South Maranhão - MA & $\begin{array}{c}\text { Minas Triangle/Upstream } \\
\text { Paranaíba - MG }\end{array}$ \\
\hline Northeast Mato Grosso - MT & Central-East Paraná - PR \\
\hline South Amazonas - AM & Bauru - SP \\
\hline Extreme West Bahia - BA & Southwest Amazonas - AM \\
\hline Juruá Valley - AC & Marília - SP \\
\hline East Goiás- GO & South Roraima - RR \\
\hline $\begin{array}{c}\text { Southwest Mato Grosso } \\
\text { do Sul-MS }\end{array}$ & Downstream Amazonas - PA \\
\hline Southwest Piauí - PI & $\begin{array}{c}\text { Southwest Rio Grande } \\
\text { do Sul-RS }\end{array}$ \\
\hline Presidente Prudente - SP & São José do Rio Preto - SP \\
\hline $\begin{array}{l}\text { Southeast Mato } \\
\text { Grosso-MT }\end{array}$ & Federal District - DF \\
\hline Northwest Paraná - PR & Pioneer North Paraná - PR \\
\hline South Goiás- GO & Itapetininga $-\mathrm{SP}$ \\
\hline $\begin{array}{l}\text { Central-South Mato } \\
\text { Grosso - MT }\end{array}$ & Southeast Paraná - PR \\
\hline Araçatuba - SP & Madeira-Guaporé - RO \\
\hline North Roraima - RR & North Central Paraná - PR \\
\hline Central Amazonas - AM & Central-West Paraná - PR \\
\hline $\begin{array}{l}\text { Northwest Minas } \\
\text { Gerais - MG }\end{array}$ & Northeast Bahia - BA \\
\hline
\end{tabular}

Source: author based on data on Municipal Agricultural Production (IBGE, 2015)

After selecting the mesoregions, they were clustered according to the pseudo-T and pseudo-F tests described above. Table 3 presents the results that were generated using SAS software (2014b; 2014c).

For the variables measured at level (L), the tests indicate a maximum of 6 groups of different spaces, 5 or 6 groups for the planted area in growth rates $(\mathrm{G})$, and a maximum of 6 representative groups for the normalized variables (NO). These values indicate 5 or 6 different spaces (areas) in terms of the growth rate for the Brazilian agricultural area.

Organizações Rurais \& Agroindustriais, Lavras, v. 19, n. 3, p. 219-232, 2017 
TABLE 3 - Groups of mesoregions in Brazilian agricultural area, 1994-2013

\begin{tabular}{|c|c|c|c|c|c|c|c|c|c|}
\hline \multirow[t]{2}{*}{ Year } & \multicolumn{3}{|c|}{ Variables at level (L) } & \multicolumn{3}{|c|}{ Variables in growth rates $(G)$} & \multicolumn{3}{|c|}{ Normalized variables (NO) } \\
\hline & Pseudo-F & Pseudo-T & Mean & Pseudo-F & Pseudo-T & Mean & Pseudo-F & Pseudo-T & Mean \\
\hline 1994 & 3 & 2 & 2.5 & - & - & - & 3 & 2 & 2.5 \\
\hline 1995 & 3 & 2 & 2.5 & 5 & 3 & 4.0 & 5 & 4 & 4.5 \\
\hline 1996 & 4 & 3 & 3.5 & 6 & 4 & 5.0 & 4 & 3 & 3.5 \\
\hline 1997 & 4 & 3 & 3.5 & 5 & 5 & 5.0 & 4 & 3 & 3.5 \\
\hline 1998 & 3 & 2 & 2.5 & 3 & 2 & 2.5 & 5 & 3 & 4.0 \\
\hline 1999 & 3 & 2 & 2.5 & 5 & 5 & 5.0 & 5 & 4 & 4.5 \\
\hline 2000 & 4 & 5 & 4.5 & 5 & 4 & 4.5 & 3 & 2 & 2.5 \\
\hline 2001 & 4 & 6 & 5.0 & 4 & 3 & 3.5 & 4 & 3 & 3.5 \\
\hline 2002 & 4 & 5 & 4.5 & 4 & 3 & 3.5 & 5 & 4 & 4.5 \\
\hline 2003 & 6 & 4 & 5.0 & 3 & 5 & 4.0 & 3 & 2 & 2.5 \\
\hline 2004 & 6 & 4 & 5.0 & 3 & 2 & 2.5 & 3 & 5 & 4.0 \\
\hline 2005 & 4 & 5 & 4.5 & 5 & 4 & 4.5 & 5 & 3 & 4.0 \\
\hline 2006 & 3 & 2 & 2.5 & 5 & 3 & 4.0 & 3 & 2 & 2.5 \\
\hline 2007 & 3 & 2 & 2.5 & 3 & 2 & 2.5 & 4 & 3 & 3.5 \\
\hline 2008 & 4 & 3 & 3.5 & 4 & 2 & 3.0 & 3 & 2 & 2.5 \\
\hline 2009 & 4 & 5 & 4.5 & 3 & 2 & 2.5 & 4 & 2 & 3.0 \\
\hline 2010 & 4 & 5 & 4.5 & 4 & 3 & 3.5 & 5 & 2 & 3.5 \\
\hline 2011 & 4 & 5 & 4.5 & 3 & 2 & 2.5 & 3 & 2 & 2.5 \\
\hline 2012 & 4 & 3 & 3.5 & 3 & 2 & 2.5 & 3 & 2 & 2.5 \\
\hline 2013 & 4 & 3 & 3.5 & 3 & 2 & 2.5 & 6 & 5 & 5.5 \\
\hline
\end{tabular}

Source: author based on data on Municipal Agricultural Production (IBGE, 2015)

Assuming five groups (areas) of different rates of growth in agricultural area, Table 4 organizes the mesoregions according to their changing share in planted area between 1994 and 2013, where the last column to the right $(\mathrm{C})$ is shown in descending order. In this column the value for the Extreme West Bahia, for instance, means that this area's share of Brazil's planted area in 2013 was 2.10 times its share in 1994.

Areas 1 to 4 experienced a participative increase of 11.41 percentage points (p.p.), 1.94 p.p., 7.21 p.p., and 3.57 p.p., respectively. These four areas accounted for $32.4 \%$ of Brazil's planted area in 1994 and for 56.53\% of the country's planted area in 2013. Accordingly, they amounted a participative increase of 24 p.p. over twenty years.

Identifying the mesoregions with similar growth in planted area from 1994 to 2013 allowed creating a map showing the dynamics of Brazil's agricultural areas based on the previously selected areas 1 to 4 , which is displayed in Figure 2.
Brazil's center-northwestern axis presented a significant expansion of planted area. In recent decades, a substantial portion of the Brazilian agricultural research was devoted to the plains areas and crops located in that region. As stated by Anderson, Pardey and Roseboom (1993), growth in agriculture depends on many factors, but the most important is the investment in agricultural research. In this context, it should be noted that several mesoregions in the center-west area experienced a minimum absolute increase of five hundred thousand hectares from 1994 to 2013. According to Helfand and Levine (2004), agricultural production and total factor productivity have grown faster in this region than in other areas since 1970 .

This route also projects towards eastern areas of the North. A second section that includes the north and northeast Mato Grosso, southern Amazonas, and the Juruá Valley must be highlighted, along with the state of Amapá, which represents a frontier area. The growth of these areas is probably related to specific 
supply chains upstream and downstream from the farms (MASTRONARDI et al., 2015), which naturally calls particular attention to sustainability in terms of social, economic $^{3}$ and environmental dimensions.

TABLE 4 - Share of selected mesoregions in planted area, 1994 and 2013

\begin{tabular}{|c|c|c|c|}
\hline & $\% 1994$ (A) & $\% 2013(\mathrm{~B})$ & $C=[(B / A)-1]$ \\
\hline North Amapá - AP & $0.001 \%$ & $0.011 \%$ & 6.60 \\
\hline East Tocantins - TO & $0.126 \%$ & $0.630 \%$ & 4.00 \\
\hline South Amapá - AP & $0.006 \%$ & $0.027 \%$ & 3.32 \\
\hline North Mato Grosso - MT & $3.092 \%$ & $11.573 \%$ & 2.74 \\
\hline South Maranhão - MA & $0.292 \%$ & $1.033 \%$ & 2.54 \\
\hline Northeast Mato Grosso - MT & $0.689 \%$ & $2.305 \%$ & 2.35 \\
\hline South Amazonas - AM & $0.019 \%$ & $0.057 \%$ & 2.04 \\
\hline (Area 1) & $4.23 \%$ & $15.64 \%$ & \\
\hline Extreme West Bahia - BA & $1.211 \%$ & $2.537 \%$ & 1.10 \\
\hline Juruá Valley - AC & $0.033 \%$ & $0.067 \%$ & 1.06 \\
\hline East Goiás - GO & $0.571 \%$ & $1.152 \%$ & 1.02 \\
\hline (Area 2) & $1.81 \%$ & $3.76 \%$ & \\
\hline Southwest Mato Grosso do Sul - MS & $2.146 \%$ & $4.134 \%$ & 0.93 \\
\hline Southwest Piauí - PI & $0.655 \%$ & $1.235 \%$ & 0.89 \\
\hline Presidente Prudente - SP & $0.503 \%$ & $0.898 \%$ & 0.78 \\
\hline Southeast Mato Grosso - MT & $1.834 \%$ & $3.038 \%$ & 0.66 \\
\hline Northwest Paraná - PR & $0.676 \%$ & $1.113 \%$ & 0.65 \\
\hline South Goiás- GO & $3.585 \%$ & $5.766 \%$ & 0.61 \\
\hline Central-South Mato Grosso - MT & $0.167 \%$ & $0.267 \%$ & 0.60 \\
\hline Araçatuba - SP & $0.543 \%$ & $0.846 \%$ & 0.56 \\
\hline North Roraima - RR & $0.037 \%$ & $0.057 \%$ & 0.53 \\
\hline (Area 3) & $10.15 \%$ & $17.35 \%$ & \\
\hline Central Amazonas - AM & $0.106 \%$ & $0.155 \%$ & 0.46 \\
\hline Northwest Minas Gerais - MG & $0.821 \%$ & $1.192 \%$ & 0.45 \\
\hline Central-West Rio Grande do Sul - RS & $0.904 \%$ & $1.264 \%$ & 0.40 \\
\hline Central-North Mato Grosso do Sul - MS & $0.782 \%$ & $1.081 \%$ & 0.38 \\
\hline Southwest Mato Grosso - MT & $0.340 \%$ & $0.459 \%$ & 0.35 \\
\hline Northeast Rio Grande do Sul - RS & $0.612 \%$ & $0.791 \%$ & 0.29 \\
\hline Minas Triangle/Upstream Paranaíba - MG & $2.189 \%$ & $2.828 \%$ & 0.29 \\
\hline Central-East Paraná - PR & $0.998 \%$ & $1.279 \%$ & 0.28 \\
\hline Bauru - SP & $0.953 \%$ & $1.213 \%$ & 0.27 \\
\hline Southwest Amazonas - AM & $0.021 \%$ & $0.027 \%$ & 0.27 \\
\hline Marília-SP & $0.163 \%$ & $0.205 \%$ & 0.26 \\
\hline South Roraima - RR & $0.024 \%$ & $0.029 \%$ & 0.23 \\
\hline
\end{tabular}

\section{Continua...}

${ }^{3}$ In the United States, for example, the connections between lower borrowing costs in land credits and increase in farmland values have been studied and there have been discussions about a possible bubble in farmland values (GLOY et al., 2011).

Organizações Rurais \& Agroindustriais, Lavras, v. 19, n. 3, p. 219-232, 2017 
TABLE 1 - Continuation...

\begin{tabular}{cccc}
\hline & $\mathbf{\% 1 9 9 4}(\mathbf{A})$ & $\mathbf{\%} \mathbf{2 0 1 3}(\mathbf{B})$ & $\mathbf{C}=[(\mathbf{B} / \mathbf{A})-\mathbf{1}]$ \\
\hline Downstream Amazonas - PA & $0.241 \%$ & $0.294 \%$ & 0.22 \\
Southwest Rio Grande do Sul - RS & $1.179 \%$ & $1.427 \%$ & 0.21 \\
São José do Rio Preto - SP & $1.388 \%$ & $1.669 \%$ & 0.20 \\
Federal District - DF & $0.159 \%$ & $0.189 \%$ & 0.19 \\
Pioneer North, Paraná - PR & $1.308 \%$ & $1.478 \%$ & 0.13 \\
Itapetininga - SP & $0.674 \%$ & $0.720 \%$ & 0.07 \\
Southeast Paraná - PR & $0.833 \%$ & $0.885 \%$ & 0.06 \\
Madeira-Guaporé - RO & $0.072 \%$ & $0.075 \%$ & 0.04 \\
Central-North Paraná - PR & $2.446 \%$ & $2.518 \%$ & 0.03 \\
\hline (Area 4) & $\mathbf{1 6 . 2 1 \%}$ & $\mathbf{1 9 . 7 8 \%}$ & -0.01 \\
\hline Central-West Paraná - PR & $1.607 \%$ & $1.599 \%$ & -0.15 \\
\hline Northeast Bahia - BA & $1.027 \%$ & $0.874 \%$ & $\mathbf{2 . 4 7 \%}$ \\
\hline (Area 5) & $\mathbf{2 . 6 3 \%}$ & $\mathbf{5 8 . 9 9 8 \%}$ \\
\hline Selected mesoregions (areas 1-5) & $\mathbf{3 5 . 0 3 2 \%}$ & $\mathbf{4 1 . 0 0 2 \%}$ \\
\hline Non-selected mesoregions (area 6) & $\mathbf{1 0 0 \%}$ & $\mathbf{- 0 . 3 7}$ \\
\hline
\end{tabular}

Source: author based on data on Municipal Agricultural Production (IBGE, 2015)

Another core expansion area includes east Tocantins, south Maranhão, southwest Piauí, and extreme west Bahia. According to Câmara et al. (2015), this area may concentrate future cropland expansion in Brazil from 2020 to 2050. Furthermore, a core of intermediate-pace expansion of planted areas includes mesoregions in northern Paraná, western São Paulo, the areas surrounding the Federal District, and the center-south of Mato Grosso do Sul.

\subsection{The Shares of Soybeans, Corn and Cotton in Agricultural Area Expansion.}

The second stage of this study calculates LQ and LGC for soybeans, corn, and cotton. As stated by Annan et al. (2013), spatial patterns of yield distributions can be crucial for their implications in crop insurance.

For soybeans, LGC had little variation along the data series, as it can be seen in Table 5. The mean LGC value was 0.295 . However, outlier points were present in specific years, such as from 2001 to 2003, and 2006; this is likely the result of random events associated with agricultural production, soybean prices, exchange rates (since soybeans are an international commodity) or even infrastructure restrictions of Brazil.

Especially about Brazil's infrastructure restrictions, $67 \%$ of the Brazilian soybeans are transported in highways (ALMEIDA, SELEME and NETO, 2013), with high production losses (NAVES, 2009 apud ALMEIDA, SELEME and NETO, 2013). This reality demands new strategies for transporting the product if soybeans area expansion continues. Furthermore, in line with Souza, Alves e Gomes (2014), infrastructure and rural extension improvements are public goods required for all Brazilian agricultural areas.

Additionally, the results for the last four years were below the mean level for the series, which can indicate reduced soybean concentration in the selected mesoregions in recent years. At the same time, the LQ of other (non-selected) mesoregions increased for the 2009-2013 period, which is consistent with the decline in LGC for soybeans. In terms of productivity, according to Bruce and Carriquiry (2010) changes in cultivated area do not result in lower soybean productivity because the crop experiences high levels of technological inputs and productive standardization.

A second aspect to highlight is the share of planted areas resulting from the selected mesoregions. For soybeans this share increased, reaching $73 \%$ of the total planted area with soybeans in Brazil in 2013, as seen in Figure 3. This result exceeded the respective level for all crops, permanent and temporary, especially between 1994 and 2006.

Some analysts (SAUER and LEITE, 2012) suggest that soybean expansion has been concentrated on Brazilian 
savannas and has a main role in deforestation process. Ferreira and Coelho (2015) endorse such argument, mainly for the northern Brazilian states.

In the context of corn production, as it can be seen in Table 6, the mean value for the LGC series was 0.016 . For such crop, LGC resulted in low or negative numbers from 1994 to 2006, but the data from 2007 to 2013 showed recent growth. Nevertheless, data from the entire series points out that corn area expansion was slightly concentrated in the selected mesoregions.
As an additional tool, partial LGCs were calculated for the years when a group of selected mesoregions had negative inputs for the LGC. This occurred in every year of the series, except for 2012-2013. Partial LGC corresponds to the coefficient matrix until the point where the contribution of the selected mesoregions is positive, excluding the group of mesoregions that had negative contributions ${ }^{4}$ to the LGC for corn.

The results for $\mathrm{LQ}$ for the non-selected mesoregions reinforce that the area expansion according to the selected

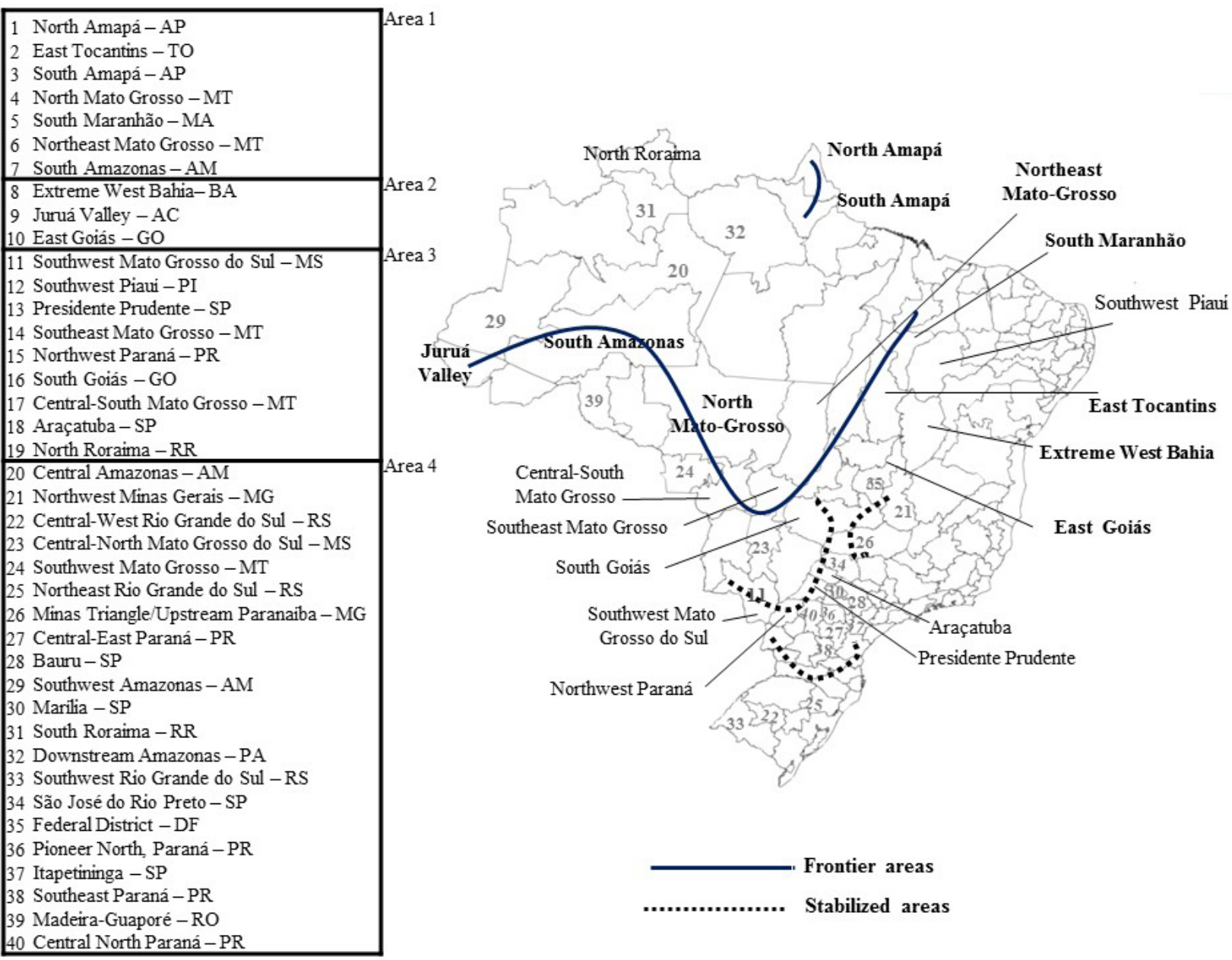

FIGURE 2 - Areas of agricultural expansion in Brazilian mesoregions, 1994-2013

Source: author based on data on Municipal Agricultural Production (IBGE, 2015)

${ }^{4}$ Further analyses can explore this negative contribution to understand the role that these areas play in the relatively low levels of LGC for corn. In mean terms, eight selected mesoregions had negative contributions to the LGC for corn from 1994 to 2011, which may have resulted from the specific criteria employed in selecting the mesoregions.

Organizações Rurais \& Agroindustriais, Lavras, v. 19, n. 3, p. 219-232, 2017 
mesoregions was not concentrated in corn. SPAROVEK et al. (2016) showed that efficiency improvements are crucial for small or medium producers, which is more evident for corn ${ }^{5}$ producers than for soybeans or cotton farmers.

TABLE 5 - LGC for soybeans and LQ for soybeans in non-selected mesoregions, 1994-2013

\begin{tabular}{ccc}
\hline Year & $\begin{array}{c}\text { LGC for } \\
\text { soybeans }\end{array}$ & $\begin{array}{c}\text { LQ for soybeans in non- } \\
\text { selected mesoregions }\end{array}$ \\
\hline 1994 & 0.301 & 0.651 \\
1995 & 0.321 & 0.621 \\
1996 & 0.292 & 0.663 \\
1997 & 0.283 & 0.669 \\
1998 & 0.296 & 0.640 \\
1999 & 0.293 & 0.640 \\
2000 & 0.306 & 0.609 \\
2001 & 0.318 & 0.591 \\
2002 & 0.320 & 0.537 \\
2003 & 0.317 & 0.563 \\
2004 & 0.300 & 0.562 \\
2005 & 0.296 & 0.557 \\
2006 & 0.317 & 0.546 \\
2007 & 0.293 & 0.582 \\
2008 & 0.298 & 0.578 \\
2009 & 0.299 & 0.578 \\
2010 & 0.279 & 0.599 \\
2011 & 0.277 & 0.600 \\
2012 & 0.253 & 0.621 \\
2013 & 0.234 & 0.652 \\
Average & 0.295 & 0.603 \\
\hline
\end{tabular}

Source: author based on data on Municipal Agricultural Production (IBGE, 2015)

Since the last two years of available data indicate a changing process, only new data can highlight this phenomenon in further studies. Simultaneously, the share for selected mesoregions in the planted area with corn resembled the pattern for all crops. In other words, corn does not differ from the general pattern of importance of selected mesoregions in terms of planted area, as illustrated in Figure 4.

In this context, Santana and Contini (2011) highlighted a forecasted increasing in domestic consumption (1.7\% per year) for corn in Brazil from 2010 to 2030.

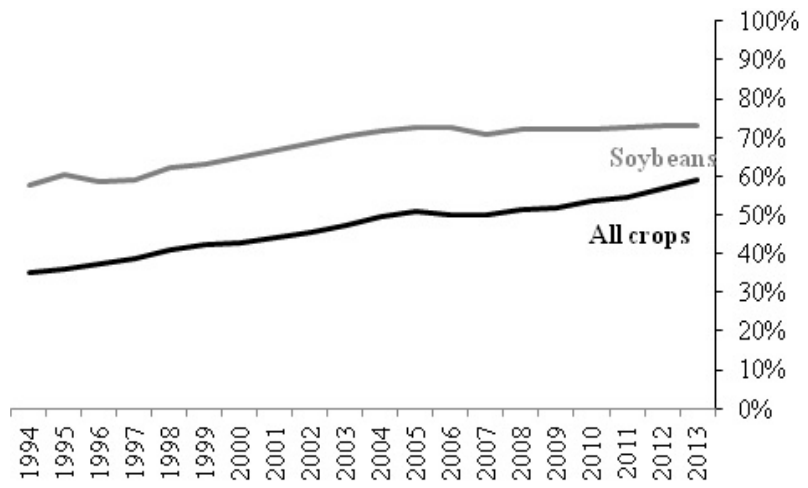

FIGURE 3 - Share of planted area in selected mesoregions, soybean and all crops, 1994-2013

Source: author based on data on Municipal Agricultural Production (IBGE, 2015)

TABLE 6 - LGC and partial LGC for corn, and LQ for corn in non-selected mesoregions, 1994-2013

\begin{tabular}{|c|c|c|c|}
\hline Year & $\begin{array}{l}\text { LGC for } \\
\text { corn }\end{array}$ & $\begin{array}{l}\text { Partial LGC } \\
\text { for corn }\end{array}$ & $\begin{array}{l}\text { LQ for corn in non- } \\
\text { selected mesoregions }\end{array}$ \\
\hline 1994 & -0.005 & 0.008 & 1.045 \\
\hline 1995 & -0.007 & 0.016 & 1.052 \\
\hline 1996 & 0.010 & 0.021 & 1.004 \\
\hline 1997 & 0.030 & 0.030 & 1.001 \\
\hline 1998 & 0.000 & 0.023 & 1.060 \\
\hline 1999 & 0.006 & 0.026 & 1.056 \\
\hline 2000 & 0.003 & 0.025 & 1.061 \\
\hline 2001 & 0.006 & 0.014 & 1.065 \\
\hline 2002 & -0.013 & 0.021 & 1.101 \\
\hline 2003 & -0.008 & 0.023 & 1.097 \\
\hline 2004 & -0.021 & 0.022 & 1.139 \\
\hline 2005 & -0.028 & 0.021 & 1.162 \\
\hline 2006 & -0.020 & 0.021 & 1.133 \\
\hline 2007 & 0.028 & 0.039 & 1.043 \\
\hline 2008 & 0.034 & 0.044 & 1.042 \\
\hline 2009 & 0.018 & 0.037 & 1.077 \\
\hline 2010 & 0.038 & 0.048 & 1.041 \\
\hline 2011 & 0.037 & 0.050 & 1.056 \\
\hline 2012 & 0.086 & $\begin{array}{c}\text { Not } \\
\text { applicable }\end{array}$ & 0.963 \\
\hline 2013 & 0.124 & $\begin{array}{c}\text { Not } \\
\text { applicable }\end{array}$ & 0.901 \\
\hline Iverage & 0.016 & 0.027 & 1.055 \\
\hline
\end{tabular}

Source: author based on data on Municipal Agricultural Production (IBGE, 2015) 


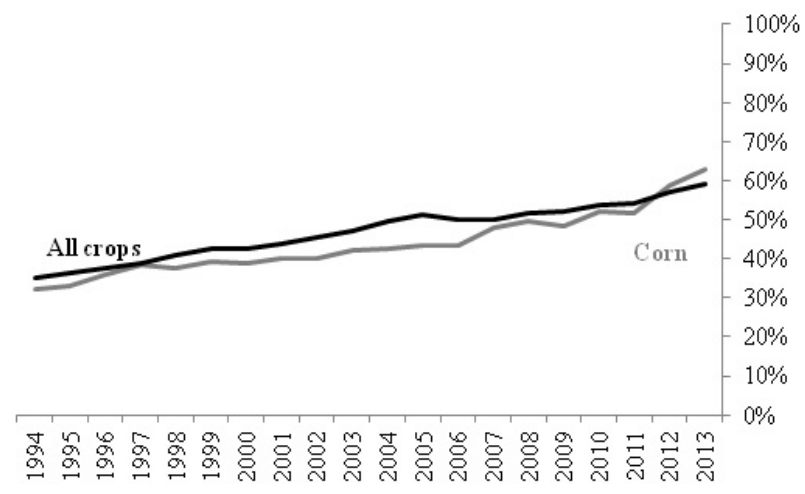

FIGURE 4 - Share of planted area in selected mesoregions, corn and all crops, 1994-2013

Source: author based on data on Municipal Agricultural Production (IBGE, 2015)

Regarding the cereal, it is mandatory to report that this crop is commonly managed in association to soybeans cycle in several Brazilian regions. The real occurrence of cereal in many areas can be underrated. Only Census data can clarify this aspect since the Municipal Agricultural Production (IBGE, 2015) does not offer any farmer individual information.

For cotton, Table 7 illustrates the ascending value for LGC. This growth is specifically located in the period 20002010. This phenomenon is more significant in cotton than in soybeans, and greatly exceeds the value for corn. Accordingly, the LQ for the non-selected mesoregions decreased during the studied period, representing the diminishing importance of the non-selected mesoregions in the area of cotton expansion.

The selected mesoregions were also more significant in cotton expansion than in all crops expansion, as it can be seen in Figure 5. This process is clear from 1997 and stabilizes in 2007 . From 2010 on, around $90 \%$ of cotton production occurred in the selected mesoregions.

According to Santo, Lima and Souza (2012) domestic uses play an important role in Brazilian cotton demand. At the same time, for some authors (LEITE and WESZ, 2010) land prices change when cattle areas are converted in cotton or soybeans cultivated areas. This way, even indirectly cotton and soybeans change the land prices in new agricultural areas.

In comparative terms, the selected mesoregions were equally representative for the expansion in corn as well as for the expansion in all crops. For soybeans, the selected mesoregions became more significant than for corn or even for all crops. Especially in recent years, three quarters of the entire planted area with soybeans was located in the selected mesoregions. Moreover, during the twenty years of the study, the share of planted area with cotton in the selected mesoregions increased substantially, with clear difference in participative expansion vis a vis the all crops situation.

Regarding this matter, Carvalho, Laureto and Pena (2015) had already detected higher productivity growth rates for cotton, corn and soybeans in the 1990's than in the 2000 's, being more evident for cotton.

In a context of area expansion guided by soybeans and cotton, even if environmental impacts happen (SAUER and LEITE, 2012), some analysts (SPAROVEK et al., 2016) consider possible to find out a common base of interests between farmers and conservationist groups.

Surely, those impacts are not limited to competition for agricultural endowments, as exposed by Brum, Dalfovo and Azuaga (2009). Their analysis about Sorriso County (MT) identified a distinguishable economic growth related to soybean production as an increased level of environmental damaging as a consequence of that increased activity.

TABLE 7 - LGC for cotton and LQ for cotton in non-selected mesoregions, 1994-2013

\begin{tabular}{ccc}
\hline Year & LGC for cotton & $\begin{array}{c}\text { LQ for cotton in non- } \\
\text { selected mesoregions }\end{array}$ \\
\hline 1994 & 0.187 & 0.861 \\
1995 & 0.274 & 0.904 \\
1996 & 0.329 & 0.595 \\
1997 & 0.153 & 0.387 \\
1998 & 0.375 & 0.762 \\
1999 & 0.412 & 0.535 \\
2000 & 0.369 & 0.723 \\
2001 & 0.538 & 0.835 \\
2002 & 0.534 & 0.692 \\
2003 & 0.523 & 0.644 \\
2004 & 0.543 & 1.174 \\
2005 & 0.560 & 1.278 \\
2006 & 0.640 & 0.958 \\
2007 & 0.708 & 1.159 \\
2008 & 0.729 & 0.177 \\
2009 & 0.718 & 0.203 \\
2010 & 0.739 & 0.172 \\
2011 & 0.718 & 0.175 \\
2012 & 0.707 & 0.179 \\
2013 & 0.689 & 0.218 \\
\hline Average & $\mathbf{0 . 5 2 2}$ & $\mathbf{0 . 6 3 2}$ \\
\hline
\end{tabular}

Source: author based on data on Municipal Agricultural Production (IBGE, 2015) 


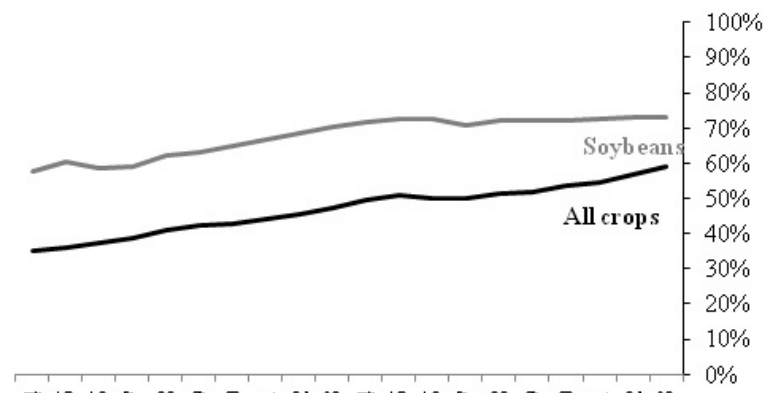

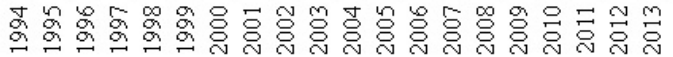

FIGURE 5 - Share of planted area in selected mesoregions, cotton and all crops, 1994-2013

Source: author based on data on Municipal Agricultural Production (IBGE, 2015)

\section{CONCLUSIONS}

This study investigated disparities in the growth of agricultural areas in the Brazilian mesoregions during the period 1994-2013 and focused on the shares of concentration for soybeans, corn and cotton in newly expanded areas.

The results detected forty-two mesoregions in six different areas of Brazil, according to their rates of expansion of agricultural area, which included a residual area containing the non-selected mesoregions. It was possible to recognize a concentration of mesoregions that experienced a significant growth in planted area in the central-west region of the country; this included mesoregions with an absolute increase of at least five hundred thousand hectares from 1994 to 2013. There is a clear center-northwest axis of expansion, especially towards eastern areas of the north and northern areas of the center-west.

In certain aspects, this phenomenon converges with another area of expansion comprised by east Tocantins, south Maranhão, southwest Piauí, and extreme west Bahia. Some areas with an intermediate pace of expansion in planted areas were also identified. Underlying this process, the selected mesoregions concentrated $90 \%$ of the area planted with cotton in Brazil. These values are also significant for soybeans (almost 75\%) and corn (63\%).

In terms of the share of growth in agricultural area per crop, the results showed the central role that is played by cotton with relation to soybeans and corn. LGC for cotton was higher than LGC for soybeans after 1998, and surpassed LGC for corn throughout the entire series. This disparity increased from 1998 to 2010 and only began to decrease in recent years. Another interesting aspect is the behavior of LGC for corn, which resembled the LGC for all crops.
Comparatively, both LGC and LQ seemed to indicate a relatively cotton concentrated expansion of agricultural areas in the selected mesoregions. This expansion is less concentrated in soybeans and even less concentrated in corn. Of course, this process can be completely different in each of the forty-two selected mesoregions, which is another point for further investigation.

This set of conclusions may support public policies related to regional aspects of agricultural expansion in Brazil, particularly for corn, soybeans, and cotton. Even though some studies, such as Câmara et al. (2015), have evaluated that Brazil is able to cope with environmental concerns and intense agricultural production, there is still space for debating.

Another important aspect is considering that soybean-cotton-corn expansion can diminish available area for producing other typical food products domestically consumed, such as beans, fruits, rice, wheat and edibles vegetables, roots and tuber. Kostandini, Mykerezi, and Escalante (2013) cited output choices among the factors affecting farm labor shortages. Indeed, these effects do not limit themselves to the agricultural labor markets; they also affect the final food price levels.

Other crops can also be included in future analysis, and consequent studies could include variables to identify reasons behind different growth rates, such as water availability or land and soil conditions. New studies are also welcome especially at country level and may explore the dynamics of specific mesoregions, analyze the supply of agricultural inputs in frontier mesoregions, or even measure productivity levels for other crops inside de identified areas.

\section{REFERENCES}

ALMEIDA, C. A.; SELEME, R.; CARDOSO NETO, J. Rodovia Transoceânica: uma alternativa logística para o escoamento das exportações da soja brasileira com destino à China. Revista de Economia e Sociologia Rural, Brasília, DF, v. 51, n. 2, p. 351-368, abr./jun. 2013.

ANDERSON, R. R.; PARDEY, P. G.; ROSEBOOM, J. Sustaining growth in agriculture: a quantitative review of agricultural research investments. Agricultural Economics, Amsterdam, v. 10, n. 2, p. 107-123, Apr. 1994.

ANNAN, F. et al. Spatial pattern of yield distributions: implications for crop insurance. American Journal of Agricultural Economics, Saint Paul, v. 96, n. 1, p. 253268, Nov. 2013. 
AWOKUSE, T. O.; XIE, R. Does agriculture really matter for economic growth in developing countries? Canadian Journal of Agricultural Economics, Ottawa, v. 63, n. 1, p. 77-99, Mar. 2015.

BARROS, J. R. M. Efeitos da pesquisa agrícola para o consumidor. In: IMPACTOS DA MUDANÇA TECNOLÓGICA DO SETOR AGROPECUÁRIO NA ECONOMIA BRASILEIRA, 2002, Brasília, DF. Anais... Brasília, DF: EMBRAPA, 2002. p. 147-202.

BERTINELLI, L.; DECROP, J. Geographical agglomeration: Ellison and Glaser's index applied to the case of Belgian manufacturing industry. Regional Studies, Brighton, v. 39, n. 5, p. 567-583, 2005.

BRANDÃO, A. S. Aumento de produtividade e exportação: uma análise exploratória. In: IMPACTOS DA MUDANÇA TECNOLÓGICA DO SETOR AGROPECUÁRIO NA ECONOMIA BRASILEIRA, 2002, Brasília, DF. Anais... Brasília, DF: EMBRAPA, 2002. p. 91-134.

BROSIG, S. et al. Introduction to the special feature: will the BRIC decade continue?: the role of rural areas and agriculture. Journal of Agricultural Economics, Malden, v. 64, n. 1, p. 145-150, Jan. 2013.

BRUCE, A. B.; CARRIQUIRY, M. An exploration of certain aspects of CARB's approach to modeling indirect land use from expanded biodiesel production. Ames: Iowa State University, 2010. (CARD Staff Report). Available at: < http://www.cardiastate.edu $>$. Access in: 14 June 2011.

BRUINSMA, J. The resource outlook to 2050: by how much do land, water and crop yields need to increase by 2050? Rome: FAO, 2009.

BRUM, A. L.; DAlfovo, W. C. T.; AZUAGA, F. L. Alguns impactos da expansão da produção de soja no município de Sorriso-MT. Desenvolvimento em Questão, Ijuí, ano 7, n. 14, jul./dez. 2009. Available at: <https://www.revistas.unijui.edu.br/index.php/ desenvolvimentoemquestao/article/view/177>. Access in: 10 Mar. 2016.

CÂMARA, G. et al. Modelling land use change in Brazil: 2000-2050. São José dos Campos: INPE, 2015.
CARVAlHO, A. X. Y.; LAURETO, C. R.; PENA, M. G. Crescimento da produtividade agrícola nas microrregiões brasileiras. Rio de Janeiro: IPEA, 2015. 62 p. (Texto para Discussão, 2099).

DEVEREUX, M. P.; GRIFFITH, R.; SIMPSON, H. The geographic distribution of production activity in the UK. Regional Science and Urban Economics, Amsterdam, v. 34, n. 5, p. 533-564, 2004.

DOĞAN, Z.; ARSLAN, S.; KÖKSAL, A. G. Historical development of agricultural accounting and difficulties encountered in the implementation of agricultural accounting. International Journal of Food and Agricultural Economics, Alanya, v. 1, n. 2, p. 107-115, 2013.

FERREIRA, M. D. P.; COELHO, A. B. Desmatamento recente nos Estados da Amazônia Legal: uma análise da contribuição dos preços agrícolas e das políticas governamentais. Revista de Economia e Sociologia Rural, Brasília, DF, v. 53, n. 1, p. 93-108, jan./mar. 2015.

FREITAS, R. E. Exportações agropecuárias brasileiras: uma avaliação do período 1989-2012. Brasília, DF: IPEA, 2014a. 42 p. (Texto para Discussão, 1964).

Produtividade agrícola no Brasil. In: NEGRI, F. de; CAVAlCANTE, L. R. (Org.). Produtividade no Brasil: desempenho e determinantes: desempenho. Brasília, DF: ABDI-IPEA, 2014b. v. 1, p. 373-409.

GASQUES, J. G.; BOTELHO, F.; BASTOS, E. T. Preço de terras e sua valorização. Brasília, DF: MAPA/AGE, 2014. 8 p.

GLOY, B. A. et al. Are economic fundamentals driving farmland values? Choices, Milwaukee, v. 26, quarter 2, p. 1-6, 2011.

HADDAD, P. R. Medidas de localização e de especialização. In: HADDAD, P. R. et al. (Org.). Economia regional: teorias e métodos de análise. Fortaleza: BNB-ETENE, 1989. cap. 4, p. 225-248.

HELFAND, S. M.; LEVINE, E. S. Farm size and the determinants of productive efficiency in the Brazilian Center-West. Agricultural Economics, Amsterdam, v. 31, n. 2/3, p. 241-249, Dec. 2004.

Organizações Rurais \& Agroindustriais, Lavras, v. 19, n. 3, p. 219-232, 2017 
HEUVEL, F. P. van den; DE LANGEN, P. W.; FRANSOO, J. Spatial concentration and location dynamics in logistics: the case of a Dutch province. Journal of Transport Geography, London, v. 28, p. 39-48, Apr. 2013.

IGLESIAS, A.; QUIROGA, S.; DIZ, A. Looking into the future of agriculture in a changing climate. European Review of Agricultural Economics, Amsterdam, v. 38, n. 3, p. 427-447, July 2011.

INSTITUTO BRASILEIRO DE GEOGRAFIA E ESTATÍSTICA. Banco Multidimensional de Estatísticas. Produção Agrícola Municipal (PAM). Rio de Janeiro, 2015.

ISARD, W. Methods of regional analysis. Cambridge: The MIT Press, 1960.

KOSTANDINI, G.; MYKEREZI, E.; ESCALANTE, C. The impact of immigration enforcement on the US Farming Sector. American Journal of Agricultural Economics, Saint Paul, v. 96, n. 1, p. 172-192, Nov. 2013.

KRUGMAN, P. Geography and trade. Cambridge: The MIT Press, 1991.

LEITE, S. P.; WESZ JUNiOR, V. Modèle de développement et dynamiques foncières au Brésil: analyse de l'expansion de l'agribusiness du soja et ses effets sur le millieu rural. Montpellier: CIRAD, 2010.

LU, Z.; FLEGG, A. T.; DENG, X. Regional specialization: a measure method and the trends in China. Munich: Munich University, 2011. (MPRA Paper, 33867). Available at: <http://mpra.ub.uni-muenchen.de/33867>. Access in: 30 Sept. 2015.

MARIN, F. R. et al. Intensificação sustentável da agricultura brasileira: cenários para 2050. Revista de Política Agrícola, Brasília, DF, ano 25, n. 3, p. 108-124, jul./set. 2016.

MASTRONARDIA, L. et al. Exploring the role of farmers in short food supply chains: the case of Italy. International Food and Agribusiness Management Review, New York, v. 18, n. 2, p. 109-130, 2015.

MINGOTI, S. A. Análise de dados através de métodos de estatística multivariada: uma abordagem aplicada. Belo Horizonte: Ed. UFMG, 2005.
NAVES, I. M. Agronegócio e logística: dicotomia. Brasília, DF: CONAB, 2009. Available at: <http://www. conab.gov.br/OlalaCMS/uploads/arquivos/82db7583 bb8bc046abd53e15459ec277.pdf>. Access in: 19 Apr. 2016.

ORGANIZATION FOR ECONOMIC AND COOPERATION DEVELOPMENT; FOOD AND AGRICULTURE ORGANIZATION OF THE UNITED NATIONS. OECD-FAO Agricultural Outlook 2014. Paris, 2014. Available at: <http://dx.doi.org/10.1787/ agr_outlook-2014-en>. Access in: 5 Mar. 2016.

REVEIU, A. E.; DARDALA, M. Quantitative methods for identification of regional clusters in Romania. Journal of Applied Quantitative Methods, Leicester, v. 6, n. 2, p. 1-11, 2011.

RUAN, J.; ZHANG, X. "Flying geese" in China: the textile and apparel industry's pattern of migration. Journal of Asian Economics, Beijing, v. 34, p. 79-91, 2014.

SANTANA, C. A. M.; CONTINI, E. Alimentos: prioridade do Brasil e do mundo! Agroanalysis, São Paulo, v. 31, n. 9, p. 16-18, set. 2011.

SANTO, B. R. E. do; LIMA, M. L. F. N. de; SOUZA, C. B. S. de. Os vinte principais mercados para exportação agrícola no futuro. Revista de Política Agrícola, Brasília, DF, ano 21, n. 1, p. 76-91, jan./mar. 2012.

SAS BUSINESS INTELLIGENCE SOFTWARE. The Cluster procedure. 2014b. Available at: <http://support. sas.com/onlinedoc/913/getDoc/pt/statug.hlp/cluster_ index.htm>. Access in: 10 Feb. 2015.

The Cluster procedure: example 23.3: cluster analysis of fisher Iris data. 2014c. Available at: $<$ http:// support.sas.com/onlinedoc/913/getDoc/pt/statug.hlp/ cluster_sect26.htm>. Access in: 10 Feb. 2015.

Introduction to clustering procedures: the number of cluster. 2014a. Available at: $<$ http://support.sas. com/onlinedoc/913/getDoc/pt/statug.hlp/introclus_sect10. htm>. Access in: 10 Feb. 2015.

SAUER, S.; LEITE, S. P. Expansão agrícola, preços e apropriação de terra por estrangeiros no Brasil. Revista de Economia e Sociologia Rural, Brasília, DF, v. 50, n. 3, p. 503-524, jul./set. 2012. 
SOUZA, G. da S.; ALVES, E. R. de A.; GOMES, E. G. Pesquisa, extensão e políticas públicas na agricultura brasileira. Revista de Política Agrícola, Brasília, DF, ano 23, n. 2, p. 69-76, abr./jun. 2014.

SPAROVEK, G. et al. Sustainable bioproducts in Brazil: disputes and agreements on a common ground agenda for agriculture and nature protection. Biofuels Bioproducts and Biorefining, Chichester, v. 10, p. 204-221, Mar. 2016.

SUZIGAN, W. et al. Coeficientes de Gini Locacionais GL: aplicação à indústria de calçados do Estado de São Paulo. Nova Economia, Belo Horizonte, v. 13, n. 2, p. 39-60, jul./dez. 2003.
UNITED NATIONS. World population prospects: the 2012 revision. Available at: <http://esa.un.org/unpd/wpp/ Excel-Data/population.htm, Total Population-Both Sexes>. Access in: 10 Apr. 2015.

VALDES, C.; HALLAHAN, C.; HARVEY, D. Brazil's Broiler industry: increasing efficiency and trade. International Food and Agribusiness Management Review, New York, v. 18, p. 263-275, 2015. Special issue A.

ZHAO, F.; HITZHUSEN, F.; CHERN, W. S. Impact and implications of price policy and land degradation on agricultural growth in developing countries. Agricultural Economics, Amsterdam, v. 5, n. 4, p. 311-324, Aug. 1991. 